\title{
Liver-derived IGF-I regulates kidney size, sodium reabsorption, and renal IGF-II expression
}

\author{
Johan Svensson, Åsa Tivesten, Klara Sjögren, Olle Isaksson, Göran Bergström', Subburaman Mohan ${ }^{2}$, \\ Johan Mölne ${ }^{3}$, Jörgen Isgaard and Claes Ohlsson
}

Department of Internal Medicine, Sahlgrenska University Hospital, Gröna Stråket 8, SE-413 45 Göteborg, Sweden

${ }^{1}$ Department of Clinical Physiology, Göteborg University, Göteborg, Sweden

${ }^{2}$ Musculoskeletal Disease Center, Jerry L Pettis Memorial VA Medical Center, Loma Linda, California, USA

${ }^{3}$ Department of Pathology, Sahlgrenska University Hospital, Göteborg, Sweden

(Requests for offprints should be addressed to J Svensson; Email: johan.svensson@medic.gu.se)

\begin{abstract}
The GH/-IGF-I axis is important for kidney size and function and may also be involved in the development of renal failure. In this study, the role of liver-derived endocrine IGF-I for kidney size and function was investigated in mice with adult liver-specific IGF-I inactivation (LI-IGF-I ${ }^{-1-}$ mice). These mice have an $80-85 \%$ reduction of serum IGF-I level and compensatory increased GH secretion. Sevenmonth-old as well as 24 -month-old LI-IGF-I ${ }^{-1-}$ mice had decreased kidney weight. Glomerular filtration rate, assessed using creatinine clearance as well as creatinine clearance corrected for body weight, was unchanged. The 24-h urine excretion of sodium and potassium was increased in the LI-IGF-I ${ }^{-/-}$mice. In the $24-$ month-old mice, there was no between-group difference in kidney morphology. Microarray
\end{abstract}

and real-time PCR (RT-PCR) analyses showed a high renal expression of IGF-II in the control mice, whereas in the LI-IGF-I $^{-/-}$mice, there was a tissue-specific decrease in the renal IGF-II mRNA levels $(-79 \%, P<0 \cdot 001$ vs controls using RT-PCR). In conclusion, deficiency of circulating liver-derived IGF-I in mice results, despite an increase in GH secretion, in a global symmetrical decrease in kidney size, increased urinary sodium and potassium excretion, and a clear downregulation of renal IGF-II expression. However, the LI-IGF-I ${ }^{-/-}$mice did not develop kidney failure or nephrosclerosis. One may speculate that liver-derived endocrine IGF-I induces renal IGF-II expression, resulting in symmetrical renal growth.

Journal of Endocrinology (2007) 193, 359-366

\section{Introduction}

The growth hormone $(\mathrm{GH}) /$ insulin-like growth factor-I (IGF-I) system is important for kidney size and function. Treatment with GH or IGF-I increases kidney size and glomerular filtration rate (GFR; Guler et al. 1988). In diabetic as well as nondiabetic end-stage renal failure, there are marked abnormalities in the GH/IGF-I system (Jain et al. 1998, Rabkin \& Schaefer 2004). In humans with diabetes mellitus (DM) type I, circulating IGF-I is low and circulating $\mathrm{GH}$ levels are compensatorily high (Carroll et al. 1998). At least in rodents, there is increased expression of IGF-I in the kidney of diabetic animals as well as multiple other changes in local renal growth factor levels (Cingel-Ristic et al. 2004, Rabkin \& Schaefer 2004). These changes could be involved in the development of the pathological glomerular changes observed in DM type I (Cingel-Ristic et al. 2004, Rabkin \& Schaefer 2004). Finally, GH as well as IGF-I treatment induces fluid retention due to increased renal sodium reabsorption (Feld et al. 1995, Hirschberg \&
Adler 1998, Cingel-Ristic et al. 2004, Rabkin \& Schaefer 2004).

The expression pattern of GH and IGF-I receptors in the kidney is complex. This is partly due to the complex structure of the kidney itself, which includes a vascular network, tubules, and an interstitial component (Rabkin \& Schaefer 2004). In the rat kidney, GH and IGF-I receptors colocalize in the thick ascending loop of Henle, whereas GH and IGF-I receptors otherwise are expressed separately (Rabkin \& Schaefer 2004). The effect of GH/IGF-I on kidney function may mainly be an IGF-I-mediated effect since the effect after GH administration is slower than that after IGF-I administration and not seen until the circulating IGF-I has been increased (Feld et al. 1995, Hirschberg \& Adler 1998). However, it has been suggested that GH can increase renal sodium reabsorption by a direct effect on the proximal tubuli (Rabkin \& Schaefer 2004).

The major part of serum IGF-I is liver derived (Sjögren et al. 1999, Yakar et al. 1999). In addition to being regulated by GH (Bengtsson et al. 1993), serum IGF-I levels are also affected by factors, such as food intake, exercise, and age 
(Landin-Wilhelmsen et al. 1994, Kaklamani et al. 1999, Ehrnborg et al. 2003). A mouse model with liver-specific inducible inactivation of the IGF-I gene, using the Cre-LoxP conditional knockout system, has been developed (LI-IGF$\mathrm{I}^{-/-}$mice; Sjögren et al. 1999, 2001, 2002, Wallenius et al. 2001, Tivesten et al. 2002). The selective inactivation of the $I G F-I$ gene in the liver results in an $80-85 \%$ reduction in serum IGF-I, whereas the renal expression of IGF-I is unaffected (Sjögren et al. 1999). These mice have increased GH secretion secondary to the decrease in serum IGF-I (geometric mean plasma GH 3.1 times higher in LI-IGF$\mathrm{I}^{-/-}$than in control mice (Sjögren et al. 1999, Wallenius et al. 2001)). In addition, as previously shown using western ligand blotting (Sjögren et al. 2002), the LI-IGF-I ${ }^{-/-}$mice have unchanged serum insulin-like growth factor-binding protein-1 (IGFBP-I) level, whereas IGFBP-2 and -3 in serum were decreased by 74 and $86 \%$ respectively, when compared with control mice.

The LI-IGF-I ${ }^{-/-}$mice do not have any major disturbance in postnatal longitudinal bone growth, whereas they have increased blood pressure (BP) due to increased peripheral resistance without any detectable effect on the reninaldosterone system (Tivesten et al. 2002). Blood glucose is normal, but circulating insulin levels are increased (Sjögren et al. 2001). Finally, kidney size is decreased (Sjögren et al. 1999). Here, we assess the role of adult expression of liverderived IGF-I for renal function, morphology, and sodium handling and investigate to what extent changes in these factors are associated with alterations in renal global gene expression.

\section{Materials and Methods}

\section{Animals and serum analyses of IGF-I and $-I I$}

The LI-IGF-I ${ }^{-/-}$mice were generated as previously described by Sjögren et al. (1999). Mice homozygous for LoxP (Liu et al. 1998), and heterozygous for Mx-Cre (Kuhn et al. 1995), were given polyinosinic-polycytidylic acid (PiPc; 6.25 $\mu \mathrm{g} / \mathrm{g}$ body weight; Sigma-Aldrich Corp.) in three i.p. injections at 4 weeks of age to induce expression of the Cre protein in the liver (Kuhn et al. 1995). PiPc-treated littermates, homozygous for LoxP but lacking $\mathrm{Mx}$-Cre, were used as controls. Seven days after the $\mathrm{PiPc}$ injections, blood was collected, and serum was assayed for IGF-I by a double-antibody IGF-binding protein-blocked RIA using a commercial kit (Mediagnost, Tubingen, Germany). In addition, in the 24-month-old mice, serum IGF-I (Mediagnost) was measured from serum collected when the mice were killed. In mice aged 9 months, serum IGF-II was measured by RIA after separation of IGFs from IGFBPs as described previously (Mohan \& Baylink 1995, Miyakoshi et al. 2001). The animals had free access to fresh water and food pellets (B\&K Universal AB, Sollentuna, Sweden). The study was approved by the ethical committee at the University of Göteborg.
Study design

In 6-month-old control $(n=7)$ and LI-IGF-I $(n=7)$ mice, serum creatinine and 24-h urine excretion of creatinine, sodium, and potassium were determined when the animals were placed in metabolic cages. Creatinine clearance was then calculated. One month later, at 7 months of age, basal tail-cuff systolic BP was assessed in these mice. Other 7-month-old mice (seven control and nine LI-IGF-I ${ }^{-/-}$mice) were anesthetized with a combination of fentanyl and fluanisone (0.55 and $17.5 \mathrm{mg} / \mathrm{kg}$; Hypnorm, Janssen Pharmaceuticals, Beerse, Belgium) and midazolam $(8.75 \mathrm{mg} / \mathrm{kg}$; Dormicum, Hoffman-La-Roche Inc., Basel, Switzerland) and were killed by rapid excision of the heart. Kidney weights were assessed and microarray analyses (kidney, liver, muscle, heart, fat, and bone) were performed. In additional experiments, 24-month-old mice (eight control and five LI-IGF-I $^{-/-}$ mice) were killed in a similar way as the 7-month-old mice, kidney weights were determined and then examinations of kidney morphology were performed. Finally, serum IGF-II levels were determined in 9-month-old mice (nine control and seven LI-IGF-I ${ }^{-/-}$mice).

\section{Systolic BP measurements}

Systolic BP was measured using a computerized noninvasive tail-cuff system (RTBP Monitor; Harvard Apparatus, Inc., South Natick, MA, USA). Unanesthetized animals were kept in a restrainer, with a standardized acclimatization time of $10 \mathrm{~min}$ and gentle heating of the tail before the recordings. Basal systolic BP measurements were performed on three separate days, with at least three recordings for each time point. Final systolic BP was obtained by averaging the mean values from the different time points.

Measurements of sodium, potassium, creatinine, and creatinine clearance

Urine was collected from LI-IGF-I ${ }^{-/-}$and control mice placed in metabolic cages during $24 \mathrm{~h}$, with free access to tap water and food pellets. Concentrations of sodium and potassium in urine were analyzed using flame photometry (FLM3, Radiometer, Copenhagen, Denmark). Creatinine in serum and urine was determined by a colorimetric method (Sigma-Aldrich Corp.). Creatinine clearance was then calculated and used as a measure of GFR (creatinine clearance $=($ urinary creatinine $) /($ serum creatinine $) \times($ urinary (low)). GFR values are given as absolute values or values corrected for body weight.

\section{Kidney morphology}

Specimens were processed from formaldehyde-fixed paraffinembedded tissue and sectioned at 3-4 $\mu \mathrm{m}$. The sections were stained with either hematoxylin and eosin or periodic acidSchiff and light microscopic examination was performed. 
All determinations of kidney morphology were performed in a blinded fashion by the same pathologist.

\section{DNA microarray analysis}

Total RNA from kidneys was extracted by Tri Reagent (Sigma) and further purified using spin columns from Rneasy Total RNA Isolation Kit (Qiagen) according to the manufacturer's instructions. RNA from 7-month-old mice (six control and seven LI-IGF-I ${ }^{-/-}$mice) was prepared. For microarray analysis, the RNA samples were pooled into two or three, resulting in three pools per group. The pooled RNA was reverse transcribed into cDNA, labeled, and analyzed by DNA microarray (MG-U74Av2 Array; Affymetrix, Santa Clara, CA, USA). The array represents 7000 mouse genes and 5000 uncharacterized expressed sequence tag clones. Preparation of labeled cRNA and hybridization were done according to the Affymetrix Gene Chip Expression Analysis manual.

The gene expression of IGF-II was also determined in microarray analyses of liver, muscle, heart, fat (retroperitoneal fat), and bone (vertebrae). These microarray analyses were performed using similar methodology as described above.

\section{Bioinformatics}

Scanned output files were analyzed using Affymetrix Micro Array Suite version 4.0.1 software (Affymetrix). To allow comparison of gene expression, the gene chips were globally scaled to an average intensity of 500. Each of the three LI-IGF-I ${ }^{-1-}$ chips was compared with the three control chips, generating nine comparison files in total. Only the genes that were regarded as 'changed,' according to the Affymetrix algorithm, in five to nine of the comparisons were selected for further analysis. An average-fold change for the nine comparisons of the selected genes was then calculated. For a gene to be regarded as regulated in the LI-IGF-I ${ }^{-/-}$ mice, the average-fold increase or decrease of the nine comparisons was set to be at least threefold. These relatively strict criteria ensured that only genes that were strongly regulated by the circulating IGF-I were detected.

\section{Real-time PCR (RT-PCR) analysis}

In order to confirm the microarray findings, RT-PCR analyses were performed (ABI Prism 7700 Sequence Detection System (PE Applied Biosystems, Stockholm, Sweden)). The RT-PCR analyses were performed on renal tissue samples from individual mice (no pooling; control mice $(n=6)$ and LI-IGF-I ${ }^{-/}$mice $\left.(n=7)\right)$. An FAM-labeled probe specific for IGF-II was used (Accession no. NM_010514, forward primer: CCGTACTTCCGGACGACTTC, reverse primer: CGTCCCGCGGACTGTCT, probe: CGTGGGCAAGTTCTTCCAATATGACACC; PE Applied Biosystems). Predesigned primers (PE Applied Biosystems) and a VIC-labeled probe for $18 \mathrm{~S}$ rRNA were included in the reactions as an internal standard. The cDNA was amplified at the following conditions: one cycle at $50{ }^{\circ} \mathrm{C}$ for $2 \mathrm{~min}$ and $95^{\circ} \mathrm{C}$ for $10 \mathrm{~min}$, followed by 40 cycles at $95^{\circ} \mathrm{C}$ for $15 \mathrm{~s}$ and $60^{\circ} \mathrm{C}$ for $1 \mathrm{~min}$. The mRNA amount of each gene was calculated using the standard curve method (multiplex reaction, following the instructions in User Bulletin no. 2, PE Applied Biosystems) and adjusted for the expression of $18 \mathrm{~S}$ rRNA.

\section{Statistical analyses}

All the descriptive statistical results are presented as the mean \pm S.E.M. Between-group differences were calculated using unpaired $t$-tests. Furthermore, for body weight, kidney weight, and kidney weight/body weight, a two-way ANOVA with age and study group as the independent variables was performed followed by Student-Neuman-Keul's multiple range test. A two-tailed $P<0.05$ was considered significant.

\section{Results}

Serum IGF-I, body weight, and kidney size

Liver-specific inactivation of the IGF-I gene was induced at 4 weeks of age, resulting in a reduction of serum IGF-I level by $80-85 \%$ in the LI-IGF-I ${ }^{-1-}$ mice when compared with the control mice (data not shown). This reduction in serum IGF-I level was sustained until 24 months of age (24-month-old LI-IGF-I ${ }^{-/-}$mice, $24 \pm 7 \mathrm{ng} / \mathrm{ml}$; 24-month-old controls, $149 \pm 21 \mathrm{ng} / \mathrm{ml} ; P<0 \cdot 001)$.

Body weight increased with increasing age, but there was no significant difference in body weight between the LI-IGF$\mathrm{I}^{-/-}$and the control mice (Table 1). Kidney weight and kidney weight per body weight were not affected by age, but both absolute and relative kidney weight were reduced in the LI-IGF-I ${ }^{-\prime-}$ mice (Table 1).

\section{GFR, BP, excretion of sodium and potassium, and kidney morphology}

In mice aged 6 months, serum and 24-h urine concentrations of creatinine were similar in the two study groups (Table 2). There was no between-group difference in GFR, as assessed using creatinine clearance or creatinine clearance corrected for body weight (Table 2). At 7 months of age, systolic BP was increased in the LI-IGF-I ${ }^{-/-}$mice (LI-IGF-I ${ }^{-/-}$mice $(n=7), 141 \pm 5 \mathrm{~mm} \mathrm{Hg}$; control mice $(n=7), 126 \pm 3 \mathrm{~mm}$ Hg; $P<0 \cdot 05)$.

The 24-h urine volume (Fig. 1A) was unchanged, whereas the 24-h urinary excretion of sodium (Fig. 1B) and potassium (Fig. 1C), determined when the mice were placed in metabolic cages, were both increased in the LI-IGF-I ${ }^{-/-}$ mice when compared with the control mice.

In 24-month-old mice, there was no change in kidney morphology in the LI-IGF-I ${ }^{-/-}$mice when compared with 
Table 1 Body and kidney weights in 7- and 24-month-old controls and $\mathrm{LI}_{-1 G F-I^{-1-}}$ mice. Kidney weights are given as the combined weight of right and left kidney. Values are given as the mean (S.E.M.). A two-way ANOVA with age and study group as the independent variables was performed followed by Student-Neuman-Keul's multiple range test

\begin{tabular}{|c|c|c|c|c|c|c|}
\hline & \multicolumn{2}{|c|}{ 7-month-old mice } & \multicolumn{2}{|c|}{ 24-month-old mice } & \multicolumn{2}{|c|}{ Two-way ANOVA } \\
\hline & Control & LI-IGF-I ${ }^{-/-}$ & Control & LI-IGF-I ${ }^{-/-}$ & $P$-value for age & $P$-value for group \\
\hline$n$ & 7 & 9 & 8 & 5 & & \\
\hline Body weight (g) & $32 \cdot 4(2 \cdot 4)$ & $32 \cdot 0(1 \cdot 8)$ & $43 \cdot 6(4 \cdot 4)$ & $36 \cdot 7(3 \cdot 9)$ & $<0 \cdot 05$ & N.S. \\
\hline Kidney weight (g) & $0 \cdot 30(0 \cdot 01)$ & $0 \cdot 26(0 \cdot 02)$ & $0.43(0 \cdot 02)$ & $0.30(0.03)^{*}$ & N.S. & $<0 \cdot 01$ \\
\hline $\begin{array}{l}\text { Kidney weight/body } \\
\text { weight }(\%)\end{array}$ & $0.94(0.03)$ & $0 \cdot 83(0 \cdot 02)^{*}$ & $1 \cdot 04(0 \cdot 09)$ & $0 \cdot 84(0 \cdot 04)$ & N.S. & $<0 \cdot 01$ \\
\hline
\end{tabular}

N.S., non significant. ${ }^{*} P<0 \cdot 01$ vs age-matched control mice using unpaired $t$-tests.

age-matched control mice (Fig. 2). There was no glomerulosclerosis or changes in the number of glomeruli, blood vessels, or tubules. No difference in mesangial cell proliferation was seen (Fig. 2). Focal inflammation but no fibrosis was seen in both LI-IGF-I ${ }^{-/-}$and control mice.

\section{Microarray and RT-PCR analyses}

DNA microarray analyses were performed to investigate if there were alterations in the global gene expression pattern in kidneys from LI-IGF-I ${ }^{-/}$mice. The analyses revealed that only three probe sets, representing FK506-binding protein 5 (FKBP51; GB U16959), Mouse A12 mRNA (GB L22977), and IGF-II (X71922), were strongly regulated (all downregulated) in $\mathrm{LI}_{-} \mathrm{IGF}_{-} \mathrm{I}^{-/-}$mice when compared with control mice (Table 3). IGF-II was, however, the only regulated gene that had a high renal expression using the Affymetrix arbitrary scale (Table 3). Furthermore, the microarray analyses showed no change in any of the members of the IGF-I family except for IGF-II (Table 3).

The expression of the IGF-II gene, as determined using microarray, was similar in the LI-IGF-I ${ }^{-/-}$and the control mice in muscle, heart, and bone (vertebra). As shown in Fig. 3A, the mRNA levels of IGF-II in control mice were considerably higher in the kidney than in the muscle, heart, and bone (Fig. 3A). In liver and fat (retroperitoneal fat), no IGF-II expression was detected using microarray (data not shown).

IGF-II was the only regulated gene that had a high renal expression using the Affymetrix arbitrary scale. Furthermore, FK506-binding protein 5 (FKBP51; GB U16959) and Mouse
A12 mRNA (GB L22977) had no obvious known relation to kidney function or morphology. Therefore, only the renal expression of IGF-II was verified using RT-PCR. The RT-PCR analyses were performed on tissue samples from individual mice (no pooling) and confirmed a clear downregulation of renal IGF-II mRNA levels in the LI-IGF-I $^{-1-}$ mice $(-79 \%, P<0.001$ vs controls; Fig. 3B). Furthermore, the renal IGF-II mRNA level, as determined using RT-PCR, correlated positively with relative kidney weight (kidney weight/body weight) in both the LI-IGF-I ${ }^{-/-}$mice $(n=7$; $r=0 \cdot 80, P=0 \cdot 01$, Fig. $3 \mathrm{C})$ and the total number of mice $(n=$ $13 ; r=0 \cdot 57, P<0 \cdot 05$; data not shown).

\section{IGF-II in serum}

The microarray and RT-PCR analyses showed a strong downregulation of the renal IGF-II mRNA levels. We therefore determined IGF-II levels in serum of 9-month-old mice. Serum IGF-II concentration was found to be similar in the two study groups as measured using RIA (mean serum IGF-II was $14 \cdot 4 \pm 1 \cdot 2 \mathrm{ng} / \mathrm{ml}$ in the LI-IGF-I ${ }^{-/-}$mice $(n=7)$ and $13 \cdot 9 \pm 2 \cdot 3 \mathrm{ng} / \mathrm{ml}$ in the control mice $(n=9) ; P=0 \cdot 6)$.

\section{Discussion}

This study shows that selective deficiency of hepatic IGF-I causes a global symmetrical decrease in kidney size. Kidney function, as assessed using creatinine clearance, was not changed and there was no sign of glomerulopathy in old

Table 2 Serum and urine creatinine levels as well as creatinine clearance in 6-month-old control and LI-IGF-I ${ }^{-/-}$mice. Values are given as the mean (S.E.M.)

\begin{tabular}{|c|c|c|c|}
\hline & Control mice & LI-IGF-I $^{-\prime-}$ mice & $P$-value \\
\hline Body weight (g) & $29 \cdot 5(2 \cdot 5)$ & $26 \cdot 2(1 \cdot 3)$ & $0 \cdot 28$ \\
\hline $24-\mathrm{h}$ urine creatinine $(\mathrm{mg} / 24 \mathrm{~h})$ & $0.43(0.08)$ & $0 \cdot 38(0 \cdot 08)$ & $0 \cdot 65$ \\
\hline Creatinine clearance $(\mathrm{ml} / 24 \mathrm{~h})$ & $31 \cdot 1(8 \cdot 0)$ & $29 \cdot 2(8 \cdot 5)$ & $0 \cdot 87$ \\
\hline $\begin{array}{l}\text { Creatinine clearance/body weight } \\
(\mathrm{ml} / \mathrm{g} \text { per } 24 \mathrm{~h})\end{array}$ & $1 \cdot 08(0 \cdot 31)$ & $1 \cdot 08(0 \cdot 28)$ & $1 \cdot 00$ \\
\hline
\end{tabular}


Control mice

- LI-IGF-I-I- mice

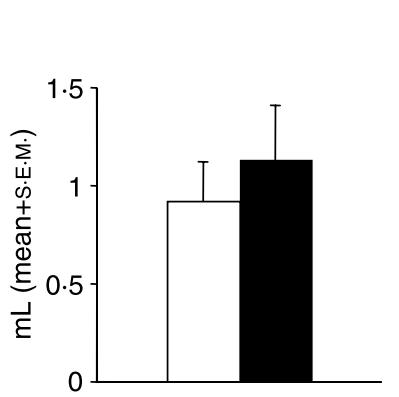

B 24-h sodium excretion

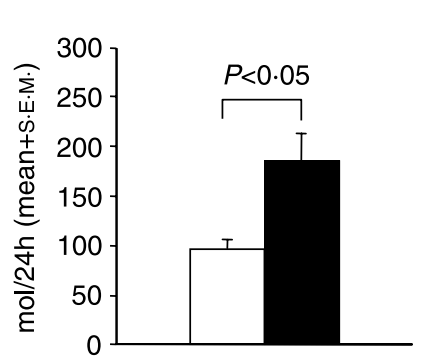

\section{A Urine volume}

Figure 1 The 24-h (A) urinary volume and (B) urine excretion of sodium, and (C) potassium, determined when the mice were placed in metabolic cages, in control $(n=7)$ and LI-IGF-I ${ }^{-1-}(n=7)$ mice. Values are given as means \pm S.E.M.
LI-IGF-I $^{-/-}$mice. However, the LI-IGF-I $^{-/-}$mice had increased 24-h urinary loss of sodium and potassium, suggesting decreased renal reabsorption of sodium and potassium. Microarray analyses, confirmed by RT-PCR analyses, demonstrated that the observed abnormalities in the LI-IGF-I $^{-/-}$mice were associated with a marked downregulation of IGF-II mRNA levels in the kidney. This decline in renal IGF-II gene expression preceded the decline in kidney growth in 7 -month-old LI-IGF-I ${ }^{-/-}$mice.

Transgenic mice with global overexpression of $\mathrm{GH}$ and/or IGF-I have selective renal enlargement and glomerular hypertrophy, whereas only the mice with global overexpression of $\mathrm{GH}$ have mesangial proliferation followed by progressive glomerulosclerosis (Doi et al. 1988, 1990, Mathews et al. 1988, Cingel-Ristic et al. 2004). Mice with global inactivation of the IGF-I gene that survive the postnatal period have reduced body weight, proportionally reduced kidney size, reduced glomerular size, and decreased number of nephrons (Rogers et al. 1999, Cingel-Ristic et al. 2004). However, these studies cannot evaluate the role of IGF-I in adult or aging animals, as they are confounded by affected IGF-I activity during development. The LI-IGF-I ${ }^{-1}$ mice do not have decreased IGF-I expression in the kidney at 3 (Sjögren et al. 1999) and 7 months of age (the present study). The inactivation of liver-derived IGF-I at 4 weeks of age resulted in a marked reduction in serum IGF-I that was maintained at 24 months of age. Therefore, although renal IGF-I expression were not determined at 24 months of age, the observed alterations were likely not, or only to a relatively small extent, due to the developmental changes in the kidney.

The histological analyses in the 24-month-old LI-IGF-I ${ }^{-1-}$ mice showed a global and symmetrical decrease in kidney size. There were no relative changes in the size, number, or distribution of renal structures, and there was no betweengroup difference in inflammation or fibrosis. Somewhat surprisingly, since the LI-IGF-I ${ }^{-/-}$mice have increased BP
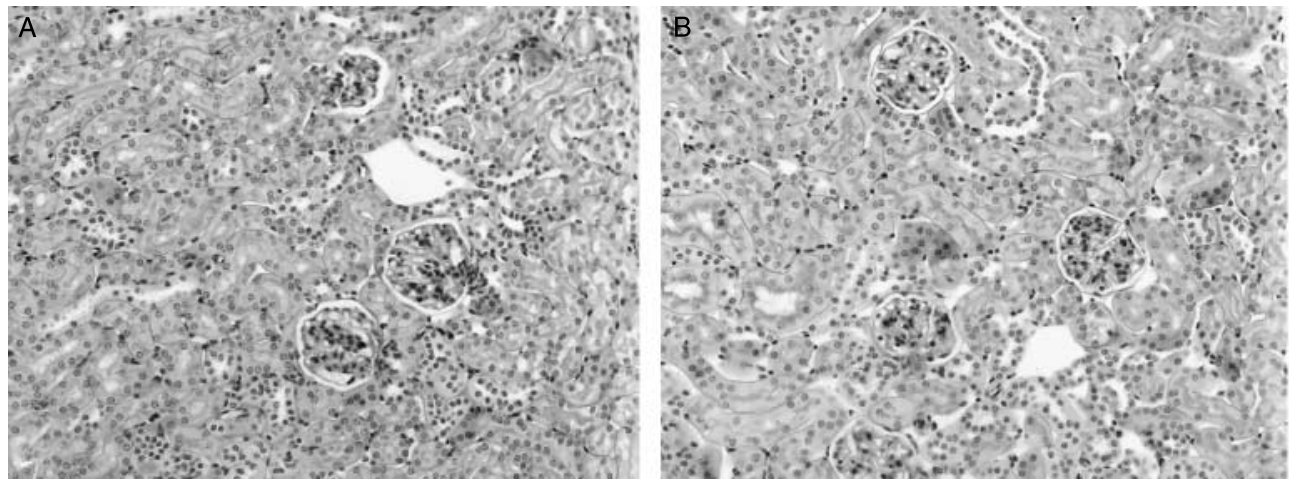

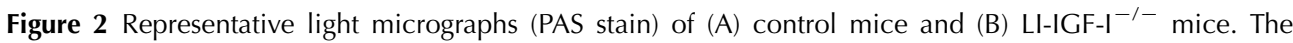
micrographs show normal cortex containing glomeruli and tubules. No glomerulosclerosis, mesangial sclerosis, or cortical fibrosis is seen. 
Table 3 Genes regulated in the kidney in 7-month-old control and

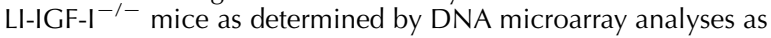
well as expression and regulation of the IGF family members as assessed using DNA microarray. The regulation of mRNA levels of different genes is indicated by the average-fold change (FC) according to the rules given in the Materials and Methods

\begin{tabular}{|c|c|c|c|}
\hline & $\begin{array}{l}\text { Genebank } \\
\text { accession }\end{array}$ & Expression & Regulation FC \\
\hline \multicolumn{4}{|l|}{ Gene } \\
\hline \multicolumn{4}{|c|}{ Regulated genes } \\
\hline FKBP51 & U16959 & + & $-11 \cdot 4$ \\
\hline $\begin{array}{l}\text { Mouse } A 12 \\
\text { mRNA }\end{array}$ & L22977 & * & $-3 \cdot 94$ \\
\hline$I G F-I I$ & X71922 & $\S$ & $-3 \cdot 31$ \\
\hline \multicolumn{4}{|l|}{$\begin{array}{l}\text { Genes from the } \\
\text { IGF family }\end{array}$} \\
\hline IGFBP-1 & X81579 & + & $\mathrm{NC}$ \\
\hline IGFBP-2 & X81580 & * & NC \\
\hline IGFBP-3 & X81581 & ND & NC \\
\hline IGFBP-4 & X76066 & $t$ & NC \\
\hline IGFBP-5 & L12447 & $\neq$ & NC \\
\hline IGFBP-6 & X81584 & ND & $\mathrm{NC}$ \\
\hline$I G F-I$ & X04480 & $t$ & $\mathrm{NC}$ \\
\hline$I G F-I R$ & AF056187 & $\neq$ & $\mathrm{NC}$ \\
\hline$I G F-I I R$ & U04710 & * & $\mathrm{NC}$ \\
\hline$A L S$ & U66900 & * & $\mathrm{NC}$ \\
\hline$G H R$ & U15012 & $\neq$ & $\mathrm{NC}$ \\
\hline
\end{tabular}

NC indicates no change according to Affymetrix. ND indicates not detectable. *, $0-500 ;+, 501-2000 ; \ddagger, 2001-8000 ; \S,>8000$ (Arbitrary units by Affymetrix).

(Tivesten et al. 2002) and compensated hyperinsulinemia (Sjögren et al. 2001), we did not find any increase in glomerulopathy or nephrosclerosis in the 24-month-old LI-IGF-I $^{-/-}$mice. However, it has previously been shown that the LI-IGF-I ${ }^{-/}$mice have decreased total body fat (Sjögren et al. 2001), which may possibly counteract the impact of the increased $\mathrm{BP}$ and the hyperinsulinemia.

Creatinine clearance and creatinine clearance corrected for body weight was similar in the LI-IGF-I ${ }^{-/-}$and the control mice. Previous studies have shown that both systemic GH and IGF-I treatment can increase GFR (Feld et al. 1995, Hirschberg \& Adler 1998, Cingel-Ristic et al. 2004, Rabkin \& Schaefer 2004). In the present study, it was not possible to correct GFR for kidney weight since it was not determined at the time when GFR was measured. However, in the LI-IGF$\mathrm{I}^{-/-}$mice, unchanged GFR combined with reduced kidney weight suggest that the smaller kidneys were functioning at similar or even increased rate when compared with that in the control mice.

GH treatment increases both serum IGF-I concentration and sodium reabsorption, resulting in fluid retention (Feld et al. 1995, Hirschberg \& Adler 1998, Cingel-Ristic et al. 2004, Rabkin \& Schaefer 2004). The LI-IGF-I $^{-/-}$mice have high circulating $\mathrm{GH}$ secondary to their low circulating IGF-I (Sjögren et al. 1999, Wallenius et al. 2001). Therefore, the present results, with increased urinary loss of sodium over $24 \mathrm{~h}$ in the LI-IGF-I ${ }^{-/-}$mice, indicate that $\mathrm{GH}$ cannot increase the renal reabsorption of sodium without a concomitant increase in serum IGF-I level, and that the combination of high circulating $\mathrm{GH}$ and low IGF-I even result in increased urinary loss of sodium. It is not clear to what extent the increased BP in the LI-IGF-I ${ }^{-/-}$mice ((Tivesten et al. 2002) and the present study) affected renal sodium handling. The increased BP in the $\mathrm{LI}_{-} \mathrm{IGF}_{-} \mathrm{I}^{-/-}$ mice is due to increased peripheral vascular resistance without
A IGF-II expression in variousorgans (determined by microarray)

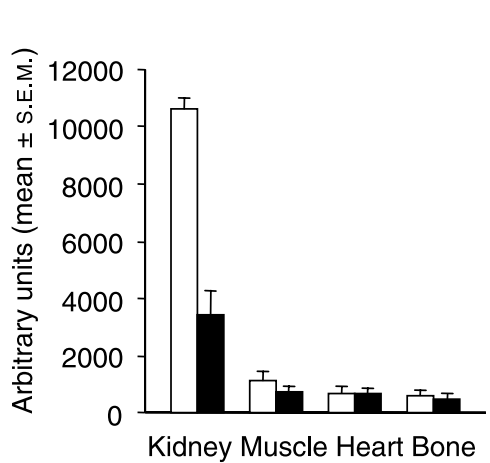

$\square$ Control mice
B Renal IGF-II mRNA level (RT-PCR; \% of that in control mice)

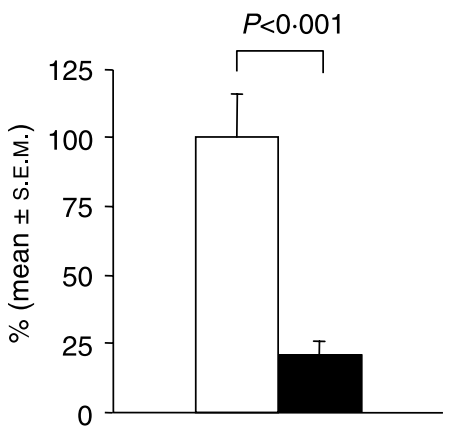

LI-IGF-I-/- mice
C Renal IGF-II mRNA level vs. relative kidney weight

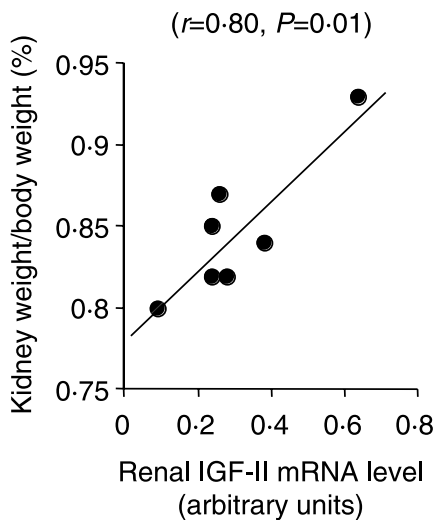

Figure 3 (A) The expression of IGF-II, as determined using microarray, in kidney, muscle, heart, and bone (vertebrae) in control ( $n=6)$ and LI-IGF-I $^{-\prime-}(n=7)$ mice. No detectable expression of IGF-II mRNA was found in the liver and retroperitoneal fat (data not shown). (B) The renal IGF-II mRNA levels, as determined by RT-PCR, in the LI-IGF-I ${ }^{-1-}$ mice $(n=7)$ expressed as percentage of that in control mice $(n=6)$. The RT-PCR analyses were performed on tissue samples from individual mice (no pooling). In Fig. 3A and B, the vertical bars indicate the S.E.M. for the mean values shown. (C) The positive correlation in the LI-IGF-I ${ }^{-/-}$mice $(n=7)$ between renal IGF-II mRNA levels, as determined using RT-PCR, and relative kidney weight $(r=0 \cdot 80, P=0 \cdot 01)$. 
any detectable effect on the renin-aldosterone system (Tivesten et al. 2002). It cannot be fully excluded that the increased sodium excretion in the $\mathrm{LI}^{-I G F-\mathrm{I}^{-/-}}$mice is a compensatory mechanism in order to counteract the $\mathrm{BP}$ elevation via a pressure-natriuretic action (Guyton 1991). However, GH treatment in humans generally increased serum IGF-I level, sodium reabsorption, and fluid retention without affecting BP (Svensson et al. 2005), thus suggesting that the effect of GH/IGF-I on renal sodium handling is independent of the BP changes. Therefore, we propose that the increased sodium reabsorption seen during $\mathrm{GH}$ treatment is mediated by the concomitant increase in circulating IGF-I.

The LI-IGF-I ${ }^{-1-}$ mice did not only have increased urinary loss of sodium but also increased urinary loss of potassium. Although the effect of GH/IGF-I on urinary potassium excretion is less well characterized than that on urinary sodium handling, decreased urinary excretion of potassium has previously been described during IGF-I treatment (Giordano \& DeFronzo 1995), and GH treatment increases total body potassium content (Bengtsson et al. 1993). In addition, increased renal IGF-I expression has been observed in potassium-depleted rats (Flyvberg et al. 1992). Potassium excretion is, to a large extent, driven by urinary flow rates (Wright 1982). The similar flow rates in the experimental groups suggest that endocrine liver-derived IGF-I interferes with specific tubular mechanisms for potassium transport. Therefore, the present and other studies suggest that IGF-I not only regulates urinary sodium handling but also urinary potassium handling.

IGF-II is of major importance for body and tissue growth in fetal life. Also in adult rodents, IGF-II mRNA and protein are abundantly expressed in the kidney (Wolf et al. 1994, Hirschberg \& Adler 1998), and transgenic mice overexpressing IGF-II have increased kidney weight (Wolf et al. 1994, Blackburn et al. 1997). In transgenic mice with global deficiency of IGF-I, global overexpression of IGF-II has no effect on body weight gain or the weight of organs except for an increase in absolute and relative kidney weight (Moerth et al. 2007). Furthermore, in vitro studies have indicated that IGF-II can increase sodium uptake in proximal tubule brush border membrane vesicles (Yanagawa et al. 1991, Feld \& Hirschberg 1996, Hirschberg \& Adler 1998). In line with these previous results, the control mice in the present study had a high renal expression of IGF-II, whereas IGF-II expression was much lower in the other organs studied (liver, muscle, heart, fat, and bone). The LI-IGF-I ${ }^{-1-}$ mice had unchanged serum IGF-II level and the kidney was the only organ studied in which the IGF-II gene was downregulated. Thus, our results demonstrate that IGF-II is highly expressed in the adult kidney where it is regulated by endocrine liverderived IGF-I in a tissue-specific manner. Therefore, one could speculate that affected IGF-II expression in the kidney could be important for the effects of circulating IGF-I on kidney size and sodium handling. This is supported by our observation of a positive correlation between renal IGF-II mRNA levels, as determined using RT-PCR, and relative kidney weight (kidney weight/body weight).
In the LI-IGF-I ${ }^{-/-}$mice (Sjögren et al. 1999, Wallenius et al. 2001), as well as in humans with DM type I (Carroll et al. 1998, Jain et al. 1998, Cingel-Ristic et al. 2004, Rabkin \& Schaefer 2004), circulating IGF-I levels are low and circulating GH levels are high. Furthermore, in animal models of type $1 \mathrm{DM}$, the discordance between circulating GH and IGF-I levels is often due to elevated glucocorticoids (Unterman et al. 1993, Rodgers et al. 1995). In the LI-IGF-I ${ }^{-\prime-}$ mice, serum corticosterone levels are increased at 1 month of age and still tend to be increased at 13 months of age (Sjögren et al. 2001). The absence of renal structural, vascular, and/or glomerular complications in the LI-IGF-I ${ }^{-/-}$mice might suggest that high circulating GH and low circulating IGF-I in itself do not cause renal failure. However, the present results do not exclude the possibility that high circulating $\mathrm{GH}$ levels combined with low circulating IGF-I levels can accelerate the renal disease in diabetic patients with already existing renal complications.

In conclusion, the LI-IGF ${ }^{-/-}$mice have a global and symmetrical decrease in kidney size and increased 24-h urinary sodium and potassium excretion. Since the LI-IGF-I ${ }^{-1-}$ mice have compensatory high circulating GH levels, the present results suggest that the well-known stimulatory effects by GH treatment on kidney size and sodium reabsorption are mediated by circulating liver-derived IGF-I. There were no signs of glomerulopathy or nephrosclerosis in the old LI-IGF-I ${ }^{-/-}$ mice, suggesting that the constellation of high circulating $\mathrm{GH}$ and low serum IGF-I is not a primary cause of diabetic or nondiabetic renal failure. The microarray analyses, confirmed by RT-PCR analyses, showed a marked decrease in the renal IGF-II mRNA levels, suggesting that the effects of circulating IGF-I on kidney size could be mediated by renal IGF-II.

\section{Acknowledgements}

This work was supported by grants from the Swedish Medical Research Council, the Swedish Foundation for Strategic Research, the Lundberg Foundation, the Torsten and Ragnar Söderberg's Foundation, the Emil and Vera Cornell Foundation, Petrus and Augusta Hedlunds Foundation, the Novo Nordisk Foundation, the Marianne and Marcus Wallenberg Foundation, and NIH (AR048139 to SM). The authors are also grateful to Maud Petersson and Anette Hansevi of the Department of Internal Medicine and Gunnel Andersson of the Department of Physiology for their excellent technical assistance. Presented in part at the Third International Congress of the GRS and the IGF Society, Kobe, Japan, November 2006. The authors declare that there is no conflict of interest that would prejudice the impartiality of this scientific work.

\section{References}

Bengtsson B-Å, Edén S, Lönn L, Kvist H, Stokland A, Lindstedt G, Bosaeus I, Tölli J, Sjöström L \& Isaksson O 1993 Treatment of adults with growth hormone $(\mathrm{GH})$ deficiency with recombinant human GH. Journal of Clinical Endocrinology and Metabolism 76 309-317. 
Blackburn A, Schmitt A, Schmidt P, Wanke R, Hermanns W, Brem B \& Wolf E 1997 Actions and interactions of growth hormone and insulin-like growth factor-II: body and organ growth of transgenic mice. Transgenic Research 6 213-222.

Carroll P, Umpleby M, Alexander E, Egel V, Callison K, Sönksen P \& Russell-Jones D 1998 Recombinant human insulin-like growth factor-I (rhIGF-I) therapy in adults with type 1 diabetes mellitus: effects on IGFs, IGF-binding proteins, glucose levels and insulin treatment. Clinical Endocrinology 49 739-746.

Cingel-Ristic V, Flyvberg A \& Drop S 2004 The physiological and pathophysiological role of the GH/IGF-axis in the kidney: lessons from experimental rodent models. Growth hormone and IGF Research 14 418-430.

Doi T, Striker L, Quaife C, Conti F, Palmiter R, Behringer R, Brinster R \& Striker G 1988 Progressive glomerulisclerosis develops in transgenic mice chronically expressing growth hormone and growth hormone releasing factor but not in those expressing insulinlike growth factor-1. American Journal of Pathology 131 398-403.

Doi T, Striker L, Gibson C, Agodoa L, Brinster R \& Striker G 1990 Glomerular lesions in mice transgenic for growth hormone and insulin-like growth factor I.I. Relationship between increased glomerular size and mesangial sclerosis. American Journal of Pathology 137 541-552.

Ehrnborg C, Lange K, Dall R, Christiansen J, Lundberg P, Baxter R, Boroujerdi M, Bengtsson B-A, Healey M, Pentecost C et al. 2003 The growth hormone/insulin-like growth factor-I axis hormones and bone markers in elite athletes in response to a maximum exercise test. Journal of Clinical Endocrinology and Metabolism 88 394-401.

Feld S \& Hirschberg R 1996 Growth hormone, the insulin-like growth factor system, and the kidney. Endocrine Reviews 17 423-480.

Feld S, Hirschberg R, Artishevsky A, Nast C \& Adler S 1995 Insulin-like growth factor I induces mesangial proliferation and increases mRNA and secretion of collagen. Kidney International 48 45-51.

Flyvberg A, Marshall S, Frystyk J, Rasch R, Bornfeldt K, Arnqvist H, Jensen P, Pallesen G \& Orskov H 1992 Insulin-like growth factor I in initial renal hypertrophy in potassium-depleted rats. American Journal of Physiology $\mathbf{2 6 2}$ F1023-F1031.

Giordano M \& DeFronzo R 1995 Acute effect of human recombinant insulin-like growth factor I on renal function in humans. Nephron 71 10-15.

Guler H, Zapf J, Scheiwiller E \& Froesch E 1988 Recombinant human insulin-like growth factor I stimulates growth and has distinct effects on organ size in hypophysectomized rats. PNAS 85 4889-4893.

Guyton A 1991 Blood pressure control - special role of the kidneys and body fluids. Science 252 1813-1816.

Hirschberg R \& Adler S 1998 Insulin-like growth factor system and the kidney: physiology, pathophysiology, and therapeutic implications. American Journal of Kidney Diseases 31 901-919.

Jain S, Golde D, Bailey R \& Geffner M 1998 Insulin-like growth factor-I resistance. Endocrine Reviews 19 625-646.

Kaklamani V, Linos A, Kaklamani E, Markaki I, Koumataki Y \& Mantzoros C 1999 Dietary fat and carbohydrates are independently associated with circulating insulin-like growth factor 1 and insulin-like growth factorbinding protein 3 concentrations in healthy adults. Journal of Clinical Oncology 17 3291-3298.

Kuhn R, Schwenk F, Aguet M \& Rajewsky K 1995 Inducible gene targeting in mice. Science 269 1427-1429.

Landin-Wilhelmsen K, Wilhelmsen L, Lappas G, Rosén T, Lindstedt G, Lundberg P-A \& Bengtsson B- $\AA 1994$ Serum insulin-like growth factor I in a random population sample of men and women: relation to age, sex, smoking habits, coffee consumption and physical activity, blood pressure and concentrations of plasma lipids, fibrinogen, parathyroid hormone and osteocalcin. Clinical Endocrinology 41 351-357.

Liu J, Grinberg A, Westphal H, Sauer B, Accili D, Karas M \& LeRoith D 1998 Insulin-like growth factor-I affects perinatal lethality and postnatal development in a gene dosage-dependent manner: manipulation using the Cre/loxP system in transgenic mice. Molecular Endocrinology 12 1452-1462.

Mathews L, Hammer R, Behringer R, D'Ercole A, Bell G, Brinster R \& Palmiter R 1988 Growth enhancement of transgenic mice expressing human insulin-like growth factor I. Endocrinology 123 2827-2833.
Miyakoshi N, Richman C, Kasukawa Y, Linkhart T, Baylink D \& Mohan S 2001 Evidence that IGF-binding protein-5 functions as a growth factor. Journal of Clinical Investigation 107 73-78.

Moerth C, Schneider M, Renner-Mueller I, Blutke A, Elmlinger M, Erben R, Camacho-Hubner C, Hoeflich A \& Wolf E 2007 Postnatally elevated levels of insulin-like growth factor-II (IGF-II) fail to rescue the dwarfism of IGF-I deficient mice except kidney weight. Endocrinology 148 441-451.

Mohan S \& Baylink D 1995 Development of a simple valid method for the complete removal of insulin-like growth factor (IGF)-binding proteins from IGFs in human serum and other biological fluids: comparison with acid-ethanol treatment and C18 Sep-Pak separation. Journal of Clinical Endocrinology and Metabolism 80 637-647.

Rabkin R \& Schaefer F 2004 New concepts: growth hormone, insulinlike growth factor-I and the kidney. Growth hormone and IGF Research 14 270-276.

Rodgers BD, Strack AM, Dallman MF, Hwa L \& Nicoll CS 1995 Corticosterone regulation of insulin-like growth factor I, IGF-binding proteins, and growth in streptozotocin-induced diabetic rats. Diabetes $\mathbf{4 4}$ 1420-1425.

Rogers S, Powell-Braxton L \& Hammerman M 1999 Insulin-like growth factor I regulates renal development in rodents. Developmental Genetics $\mathbf{2 4}$ 293-298.

Sjögren K, Liu J, Blad K, Skrtic S, Vidal O, Wallenius V, LeRoith D, Törnell J, Isaksson OG, Jansson J-O et al. 1999 Liver-derived insulin-like growth factor I (IGF-I) is the principle source of IGF-I in blood but is not required for postnatal body growth in mice. PNAS 96 7088-7092.

Sjögren K, Wallenius K, Liu J, Bohlooly YM, Pacini G, Svensson L, Törnell J, Isaksson OG, Ahren B, Jansson J-O et al. 2001 Liver-derived IGF-I is of importance for normal carbohydrate and lipid metabolism. Diabetes $\mathbf{5 0}$ 1539-1545.

Sjögren K, Sheng M, Moverare S, Liu J, Wallenius K, Törnell J, Isaksson OG, Jansson J-O, Mohan S \& Ohlsson C 2002 Effects of liver-derived insulinlike growth factor I on bone metabolism in mice. Journal of Bone and Mineral Research 17 1977-1987.

Svensson J, Tivesten A \& Isgaard J 2005 Growth hormone and the cardiovascular function. Minerva Endocrinologica 30 1-13.

Tivesten A, Bollano E, Andersson I, Fitzgerald S, Caidahl K, Sjögren K, Skott O, Liu J, Mobini R, Isaksson OG et al. 2002 Liver-derived insulin-like growth factor-I is involved in the regulation of blood pressure in mice. Endocrinology 143 4235-4242.

Unterman TG, Jentel JJ, Oehler DT, Lacson RG \& Hofert JF 1993 Effects of glucocorticoids on circulating levels and hepatic expression of insulin-like growth factor (IGF)-binding proteins and IGF-I in the adrenalectomized streptozotocin-diabetic rat. Endocrinology 133 2531-2539.

Wallenius K, Sjögren K, Peng X, Park S, Wallenius V, Liu J, Umaerus M, Wennbo H, Isaksson OG, Frohman L et al. 2001 Liver-derived IGF-I regulates GH secretion at the pituitary level in mice. Endocrinology 142 $4762-4770$.

Wolf E, Kramer R, Blum W, Föll J \& Brem G 1994 Consequences of postnatally elevated insulin-like growth factor-II in transgenic mice: endocrine changes and effects on body and organ growth. Endocrinology 135 $1877-1886$.

Wright F 1982 Flow-dependent transport processes: filtration, absorption, secretion. American Journal of Physiology Renal Physiology 243 F1-F11.

Yakar S, Liu J, Stannard B, Butler A, Accili D, Sauer B \& LeRoith D 1999 Normal growth and development in the absence of hepatic insulin-like growth factor I. PNAS 96 7324-7329.

Yanagawa N, Sheikh-Hamad D \& Jo O 1991 Insulin-like growth factor II directly increased renal brush border membrane sodium transport. Journal of the American Society of Nephrology 2447 (Abstract).

\section{Received in final form 12 March 2007 \\ Accepted 28 March 2007 \\ Made available online as an Accepted Preprint 30 March 2007}

